\title{
Tourism Development Plan for District of Bastar
}

\author{
Shubham Yadav \\ Department of Urban Planning, Chhattisgarh Swami Vivekanand Technical University, Bhilai, \\ Chhattisgarh, 491107, India. \\ Corresponding author, E-mail address: yshubham0819@gmail.com \\ Received July 1, 2019; received in revised form July16, 2019; July 16 2019; Available online
} July 2019

\begin{abstract}
Bastar is a tribal region in Chhattisgarh state of India. The region is blessed with exceptional scenic beauty for nature lovers, the region can be well explored with waterfall, forests, tribal dance, music, wildlife, ancient temple. State capital is $264 \mathrm{~km}$ from this region. It has lot to offer to its visitors that lie in and around lush green of district headquarter Jagdalpur, which is significant eco-friendly destination in the region.
\end{abstract}

Keywords: Tourism, Facilities management, Lodging Management, Chitrakoot, Bastar

\section{Introduction}

Bastar is a land richly woven by its vibrant people and decorated by the beautiful blossoms of mother nature. A treasure trove of many mysteries, the doors of this land have opened to many dynasties, invaders, traders, and travellers hidden in the deep sal, teak, and bamboo forest are many secrets of nature's wealth. Bastar is like a rare, sparkling jewel on the royal crown of Chhattisgarh, sharing borders with Maharastra, Andhra Pradesh and Odisha. Bastar is a giant chest full of myriad wonder and undiscovered surprises like the kanger valley national park, unique species of flora and fauna, mystical caves, mesmerising waterfalls, vibrant festivals coupled with equally warm and interesting tribal folks. adventures, explorers, archeologists and tribal culture experts are allured by the endless treasures of Bastar.
With so much of flora and fauna,bastar is considered to be the richest ecological biodiversity in the country of India. and the honored identity of Bastar is given by the united nations as one of the biodiversity hotspots in India.the rainy seasonshows beautiful picture of the springs and waterfalls surrounded by the green fields around. the winter is full of fog, very much advisable for early morning's sunrise views and bonfire nights with camping and trekking all along the woods. these seasons are best to visit Bastar and explore the scenic beauty the most.

The landcover of district shows maximum of forest area $57 \%$ which makes it culturally intensive and vibrant centre for recreation. Lodging operations are an intrinsic part of the hospitality industry. Lodging facilities that were used for economic purposes were built along transportation routes where traveling 
parties found it convenient to make rest stops route to their destinations.. In this context the questions arise: What is Facilities Management, what can it offer to the tourism industry and how does Facilities Management improve the tourism industry in Bastar? In Bastar tourism can be a effective means to do logistic phenomenon. Tourism in Bastar can lead to know its image to the world. However, the major issue can be addressed with respect to tourism is provision of basic amenities. To sort out this problem facility management can be adopted as best possible solution? It is crucial for the tourism industry in Bastar, be able to compete at global level by increasing productivity, maximising the overall equipment effectiveness maintenance program. This paper seeks to analyse the role of facilities management in the tourism industry, and whether, it could help towards realising sustainable tourism development in the future. There is lack in awareness about tourist destination and unidentified spots and limited number of package tours with respect to number of tourist operators and provision of basic amenities. The author attempted to examine the aspects of tourism market and its expansion to offer strategy for the sustainable growth of tourism in the district of Bastar. Also aimed to study various factors responsible for hurdle in the increase, commercialization of tourism market and provide sufficient infrastructure.

The realm of study has been confined to Bastar region area. In the light of objectives, the scope of study has been limited to phenomenon of district and problems, related to transportation, accommodation, recreation, environment and ecology and community facilities. The limitation of work is engineering details will not be accounted like cutting and filling for construction of infrastructure facilities, shortage of manpower, resources and time are a limitation especially for the study or survey part of the study. The area of Bastar district is very large limited survey of two to three percent is considered.

\section{Methodology}

The study is conducted on all the three basis of planning, i.e social, eeconomical and political. To understand the increase in tourism market and tourist with respect to different tourist spots. Both primary and secondary data are collected during survey. Primary data is collected through scheduled interview, field survey and tourist feedback. In case of secondary data, it is collected from statistical report, government data and internet.

\subsection{Coverage of the study}

Nature Tourism - Bastar is full of natural beauty. The region have Kutumser caves, Chitrakotewaterfall, Tirathgarh Waterfall.

Wildlife Tourism - Bastar has a rich and dense forest cover with beautiful and exotics like Kanger Valley National Park, Indravati National Park

Rural Tourism-A famous tribal village Nangur where main tribal groups are Tribal, Abujhmaria Tribal, Bison Horn Tribal, Muria and Halba Tribal Gonds. Bastar district has tribal tour Circuit.

Cultural Tourism- The cultural fairs and festivals in Baster region are Lokotsav and Dussehra (span over 75 days), Goncha Festival and others tribal festivals.

Adventure Tourism- Tourism, in some places of Bastar region like tirathgarh, chitrakot,the tourist go for trekking in various rugged 
mountains of this area and alsodo mountaineering, Paragliding Water Sports

\subsection{Research Questions Considered are:}

1. Is price the main influence for ecotourism destinations among tourists?

2. Does the life style of tribal people change with increase in tourism?

3. How Does ecotourism economically benefit local communities?

4. Examining the benefits of integrated marketing communication to ecotourism in the Chhattisgarh?

\subsection{Hypothesis}

Promotion of tourism is important for tourism growth in the region, when planning for trips are considered, tourist consider factor like social, psychological benefits. Tourist perceive social media site as reliable to get to know information about tourist destination.

The land cover of district shows maximum of forest area $57 \%$ which makes it culturally intensive and vibrant centre for recreation.

\section{Result and observation}

There are two general circuits Chitrakoot circuit and Kanger valley national park circuit. The forest department of Bastar district take into account the infrastructure and tourist promotion in the form of Construction of Bio Toilet, Redevelopment of Tourist Cottage, Construction of Glass House, Watch Tower Beside Both Side of Waterfall for Tourist, Benches Near Dandak Caves for Tourist for which the fund allotment is both by central and state department. Whereas the development along Chitrakoot circuit is taken by Collector by the revenue collected by irrigation and other local bodies departments.

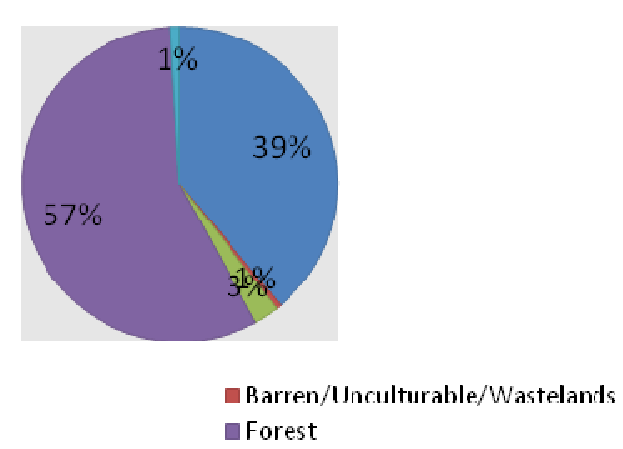

Figure 1 Infrastructure in terms of units in Bastar

The two on going schemes by Central government are the Tribal Circuits and Ramayana Circuit. Under Tribal Circuits, the aim is to develop and promote these tribal areas in a very responsible manner with due focus on cultural sensitivities, carrying capacity and preservation of natural surroundings and local culture (Table 1).

Table 1 Detail of infrastructure in terms of units.

\begin{tabular}{|l|l|}
\hline Infrastructure & No. of Units \\
\hline Tourist Information Centre & 2 \\
\hline Police Post & 19 \\
\hline Banks & 20 \\
\hline Private Hotels & 29 \\
\hline
\end{tabular}

Another circuit the Ramayana Circuit aimed at developing and connecting the places associated with lord Ram across the country and will bridge infrastructural gaps, improve the tourist facilities, promote cultural and heritage value, develop local art and craft and provide tourist experience. 
Table 2 Tourist Growth rate

\begin{tabular}{|c|c|c|c|c|c|c|}
\hline \multicolumn{7}{|c|}{ TOURIST TRAFFIC } \\
\hline 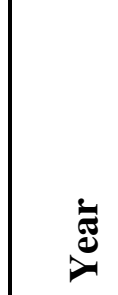 & 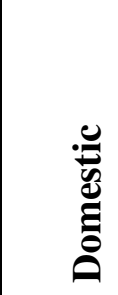 & 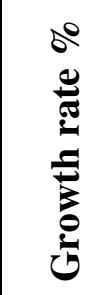 & & ט. & อี & 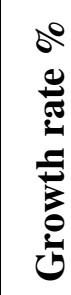 \\
\hline 2012 & 90476 & - & 142 & - & 90618 & \\
\hline 2013 & 64894 & 39.4 & 150 & 5.3 & 65044 & 39 \\
\hline 2014 & 81878 & 2.01 & 172 & 12.7 & 82050 & $\begin{array}{c}20 \\
.7\end{array}$ \\
\hline 2015 & $\begin{array}{l}11370 \\
2\end{array}$ & 27.0 & 134 & 28.0 & $\begin{array}{l}11383 \\
6\end{array}$ & $\begin{array}{c}27 \\
.0\end{array}$ \\
\hline 2016 & $\begin{array}{l}19326 \\
0\end{array}$ & $\begin{array}{l}41.0 \\
1\end{array}$ & 128 & 4.0 & $\begin{array}{l}19338 \\
8\end{array}$ & $\begin{array}{l}41 \\
.1\end{array}$ \\
\hline 2017 & $\begin{array}{l}24855 \\
4\end{array}$ & 21.2 & 170 & 24.7 & $\begin{array}{l}74566 \\
2\end{array}$ & $\begin{array}{l}22 \\
.2\end{array}$ \\
\hline
\end{tabular}

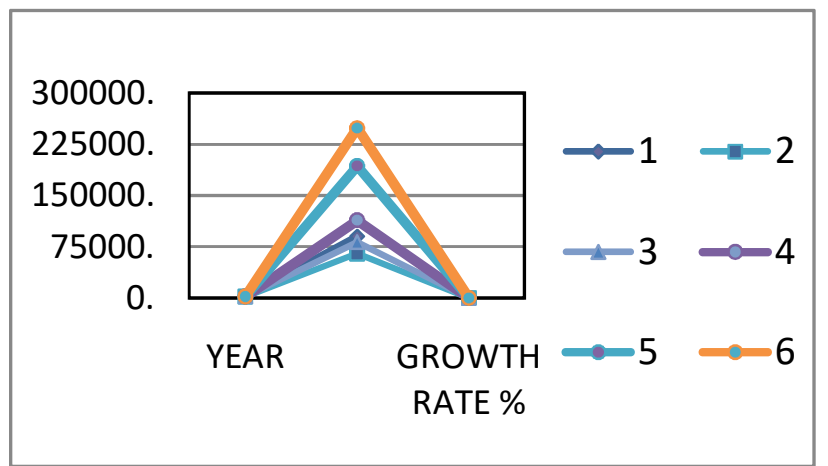

Figure 2 Domestic growth rate

In terms of protection four monument / sites are protected by archaeological survey of
India and fifteen monument/sites By Direcorate of culture \& archaeology, cultural department-govt. of C.G.

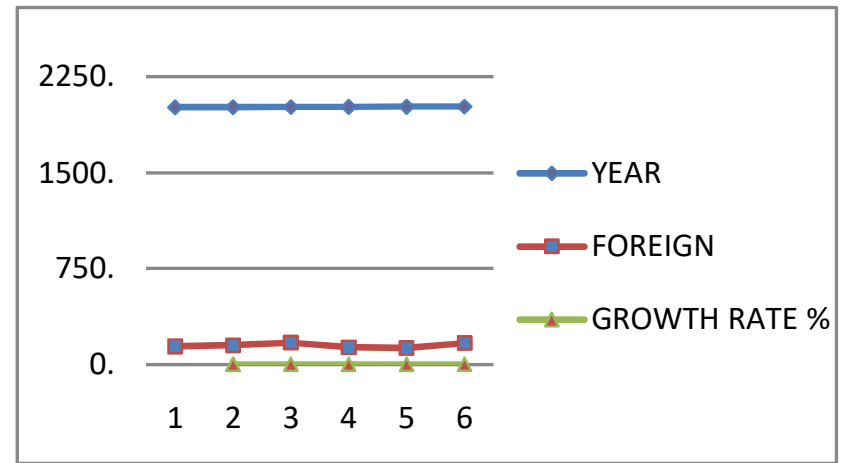

Figure 3 Foreign growth rate

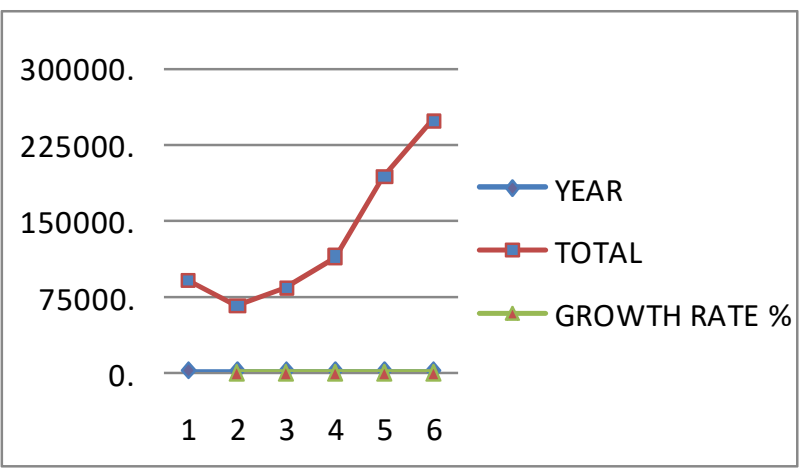

Figure 4 Total growth rate

\subsection{Growth rate analysis}

The growth rate of tourist within five year is 30.06\% from 2012 to 2017 (table 2, Fig 2-4). The ratio of Foreign to Domestic tourist in 2014 is 1:1461 due to National and state level Festival, thus impact of Domestic will have larger to the area.The best possible option for promotion is through fairs, advertisement and other material.

There are total of 6 Travel Agents and Season of Tourism is from October to March. Tourist traffic has been decrease in the year of 2013 due to Lack of proper accomodation. 


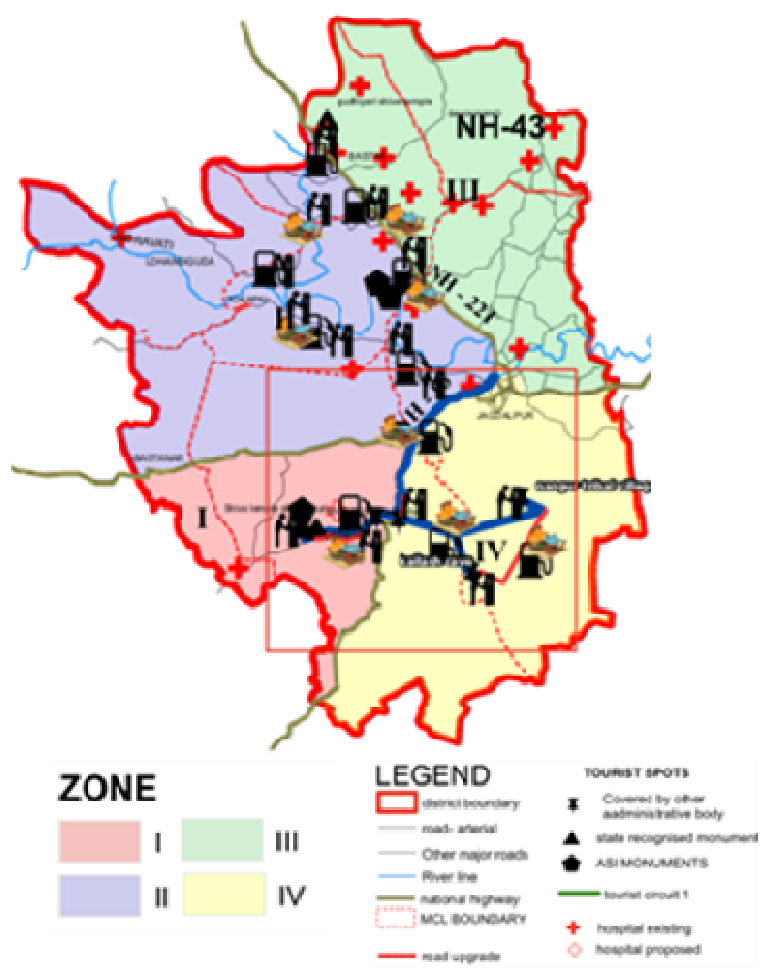

Figure 5 Division of Bastar - Zone 1

Table 3 Accommodation available

\begin{tabular}{|c|c|c|c|c|c|c|c|}
\hline $\begin{array}{c}\text { S.N } \\
\text { o }\end{array}$ & Zone & $\begin{array}{c}\text { Hotel } \\
\text { Numbe } \\
\mathbf{r}\end{array}$ & $*$ & $* *$ & $* * *$ & $* * *$ & $* *$ \\
$*$ & $\begin{array}{c}\text { ZONE } \\
1\end{array}$ & 27 & 1 & 2 & 20 & 3 & 1 \\
\hline 2 & $\begin{array}{c}\text { ZONE } \\
2\end{array}$ & 2 & 1 & - & 1 & - & - \\
\hline
\end{tabular}

The tourist Place which are connected with kanger valley national park Circuit have Good access and Tourist Infrastructure. The solution for tourist promotion can be in context of development of Bastar tourist circuit art exhibition festival promotion of Bastar culture, by providing infrastructure and employment generation.

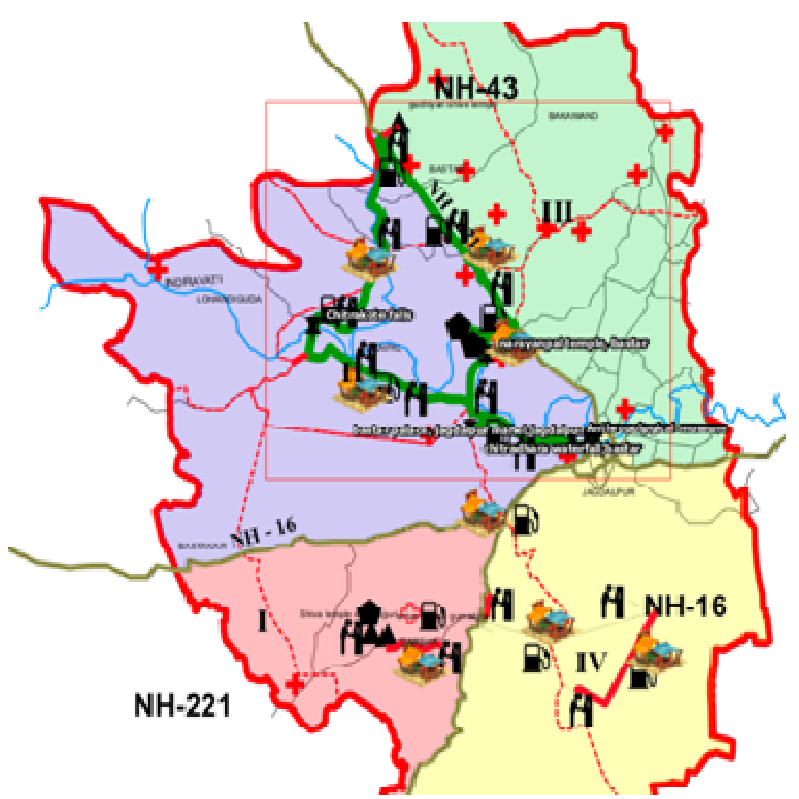

Figure 6 Division of Bastar - Zone 2

\subsection{SWOT Analysis}

Strength: Six of the Place are connected with the Kanger valley Circuit.3 of ASI monuments are located in Bastar District, and 15 by Direcorate of culture and archaeology, cultural department-govt. of C.G

Weakness: Tourism infrastructure (Accommodation, Connectivity and Promotion). Less importance District compare to other District of Chhattisgarh in context of Tourism.

Opportunities: Inventory of potential locations and For increasing season. Promote Industry for the Handicraft of Bastar.

Threat: Some tourist spots are seasonal and during rainy season Kotumsar cave is not safe.

Other than that no Designated markets and exhibition for Handicrafts Industry.Most of the Place are Un-Explored by tourist.Lack of Tourist Infrastructure like Accommodation, 
access and Information centre and Lack of tourist guide

The moderate accessibility to the tourist spot and lack in accommodation facility in Kanger valley tourist circuit .The tourist Place which are connected with Kanger valley National park Circuit have Good access and Tourist Infrastructure compare to the rest of the places.

According to public opinion the maximum problem is faced on sites like Tamra ghumar and Nangur Village got the bad access and poor tourist infrastructure. Foreign tourist faces maximum problem with shortage of ATM;s at regular interval, not even within a range of $20 \mathrm{~km}$ from tourist spots.Tourism Infrastructure mainly includes the tourist information centre, hotels, parking areas, food points, signages, etc. A total of 29 hotels are found in the area including a tourist information canter in Jagdalpur. The hotels are mainly private. Problems faced by tourists is less number of public toilets and location of the toilets was another problem faced. Conditions of parking areas were not appropriate, parking areas for hotels were not provided and no proper availability of source for guidance of tourists.

\subsection{Problems and Potentials}

Tourist faced problems as the parking area at some spota were unpaved, which causes problems in rainy seasons.there is lack in Tourist information center, which can only be seen in district headquarter, No water pipeline to tourist spot and public toilet not connected to sewage line. Signage were only in local language because of which foreigner faced problem.

Many tourist sites are found in and around the city which provide more options for tourist, large number of tourist activities like fair, water-sports etc are held to attract tourist. Tourism infrastructure like hotels, banks, banks Atm's etc are available in district headquarter, near to tourist spot small branches of bank can be find, 3 monuments /sites are protected by archeological survey of India, and other 3 by District By Directorate of culture \& archaeology, cultural department-Govt. of C.G

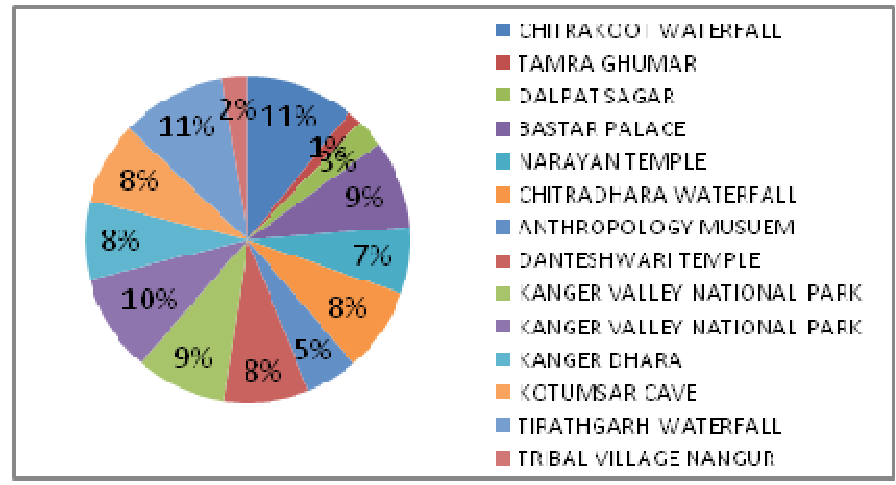

Figure 7 Total growth rate

Maximum number of tourist visit is on chitrkoot and tirathgarh waterfall, with maximum satisfaction level. Tourist spot like Tamra ghumar and tribal village Nangur face problem with accessibility, infrastructure and accommodation. Overall, the public opinion demand maximum is for ATM's, restaurant, and accommodation.

Problems can be seen like No. of Designated markets and exhibition for handicrafts Industry is very low.Most of the Places are Un- Explored by Tourist. Insufficient accessibility to tourist spot, leads to lower the tourist inflow. Number of accommodation services meet the requirement of tourist in zone 1.No. of hotel bed in all the total 29 
hotel, do not meet requirement of tourist in zone 2. ( Kanger valley national park circuit)

Table 4 Roads connectivity and status

\begin{tabular}{|l|l|l|l|}
\hline Roads & $\begin{array}{l}\text { Connectivit } \\
\mathbf{y}\end{array}$ & $\begin{array}{l}\text { Length of } \\
\text { Road }\end{array}$ & Status \\
\hline $\begin{array}{l}\text { New } \\
\text { road }\end{array}$ & $\begin{array}{l}\text { Tirathgarh to } \\
\text { Nangur }\end{array}$ & $10 \mathrm{KM}$ & $\begin{array}{l}\text { one lane } \\
\text { road }\end{array}$ \\
\hline $\begin{array}{l}\text { New } \\
\text { road } \\
\text { Kama } \\
\text { Demorial to }\end{array}$ & $3.5 \mathrm{KM}$ & $\begin{array}{l}\text { Two lane } \\
\text { road road }\end{array}$ \\
\hline $\begin{array}{l}\text { Upgrade } \\
\text { road }\end{array}$ & $\begin{array}{l}\text { Kangerdhara } \\
- \text { Tirathgarh } \\
\text { road }\end{array}$ & $11 \mathrm{KM}$ & $\begin{array}{l}\text { one lane } \\
\text { road }\end{array}$ \\
\hline $\begin{array}{l}\text { Upgrade } \\
\text { road }\end{array}$ & $\begin{array}{l}\text { Chitrakot }- \\
\text { Tamraghum } \\
\text { ar road }\end{array}$ & $15 \mathrm{KM}$ & $\begin{array}{l}\text { Two lane } \\
\text { road }\end{array}$ \\
\hline $\begin{array}{l}\text { Upgrade } \\
\text { road }\end{array}$ & $\begin{array}{l}\text { Chitradhara } \\
- \text { Chitrakot } \\
\text { road }\end{array}$ & $8 \mathrm{KM}$ & $\begin{array}{l}\text { Two lane } \\
\text { road }\end{array}$ \\
\hline
\end{tabular}

Strategies can be followed as Bastar Tourist Circuit Art Exhibition Festival Promotion Of Bastar Culture, By Providing Infrastructure and Employment Generation

\section{Conclusion: Proposals and suggestion}

Local bus stands are provided at the major tourist spots to stand the local bus because there were no as such facilities and bus stands are located at that spots where maximum routes are divergent. Eating joints are provided in almost all the tourist spots for the convenience of tourists. ATM's and dust bins are provided in all the tourist spots in appropriate locations. Provision of tourist information centre. More number of tourist operators, water sports, Boating station, Para shutting are to be proposed. Tourist information centre has been provided in tourist circuit 2 to know the information about the tourist destinations. Police post has been proposed. In chitradhara, tirathgarh area to provide security in Tourist spots. Take away meals have been provided in kangervalley national park area because these points are the junctions where two roads were meet. Public toilets have been provided at different tourist spots wherever needed and improves the condition of the existing public toilets.

\section{Conflict of interest}

The author declares no conflict of interest.

\section{References}

1. Simmons D (1994) Community participation in tourism planning. Tourism management 15: 98-108.

2. Dowling R (1993) An Environmentally based Planning Model for Regional Tourism Development. Journal of Sustainable Tourism 1: 17-37.

3. http://bastar.gov.in/en/nature-and-tourism

4. Tourism Policy, Ministry of Tourism, Govt. of India, Delhi, India (2002). 